\title{
Turizm Lisans Öğrencilerinin Turizm Sektöründe Çalışma Eğilimleri Üzerine Bir Araştırma
}

\section{A Research on Undergraduate Tourism Students' Intention to Work in Tourism Industry}

\author{
Dr. Hasan KÖŞKER \\ Bitlis Eren Üniversitesi \\ Adilcevaz Meslek Yüksekokulu \\ E-posta: hasankosker@yahoo.com \\ Orcid Id:0000-0003-0662-8301
}

Doç. Dr. Kamil UNUR

Mersin Üniversitesi

Turizm Fakültesi

E-posta: kunur@yahoo.com

Orcid Id:0000-0003-2992-7427

\section{Öz}

Bu araştırmanın temel amacı, turizm lisans öğrencilerinin turizm sektöründe çalışma eğilimlerine (TSÇE) yönelik tutumlarını ortaya koymaktır. Çalışmada tabakalı örnekleme yöntemi kullanılmıştır. Bu doğrultuda Türkiye'nin her bölgesinden en çok öğrencisi olan bir fakülte veya yüksekokul seçilerek, öğrenci sayısının büyüklüğü ile doğru orantılı örneklem alınmıştır. Anket yoluyla 800 katılımcıdan elde edilen verilerin analizi için t-testi ve tek yönlü ANOVA kullanılmıştır. Araştırmada kadınların erkeklere, okuduğu bölümü isteyerek seçenlerin istemeyerek seçenlere kıyasla TSÇE'ne yönelik tutumları, anlamlı bir şekilde yüksek bulunmuştur. Staj/mesleki deneyimi olmayanların, staj/mesleki deneyimi olan katılımcılara kıyasla TSÇE'ne yönelik tutumlarının anlamlı bir şekilde daha yüksek olduğu tespit edilmiştir.

Anahtar Kelimeler: Turizm eğitimi, turizm lisans öğrencisi, turizm sektöründe çalışma eğilimi.

\section{Abstract}

The aim of this research is to reveal undergraduate tourism students' intention to work in tourism industry. Quota sampling method was used by selecting a faculty or a high school which has the highest number of undergraduate tourism students from each region of Turkey. Data was collected from 800 participants by a questionnaire. T-test, one-way ANOVA have been used for data analysis. As a result of the study intention to work in tourism industry scores of women and those who preferred the school consciously are higher than the opposite groups. The scores of the participants who did not have apprenticeship or professional experience are higher than the group who have apprenticeship or professional experience in tourism industry.

Keywords: Tourism education, undergraduate tourism student, intentions to work in tourism industry. 


\section{Giriş}

Başta bilişim ve ulaşım olmak üzere tüm alanlarda süreklilik gösteren gelişmeler turizm sektörünün sosyal, siyasal, kültürel ve ekonomik etkilerini her zamankinden daha fazla arttırarak sektörü daha önemli bir konuma taşımaktadır (Gee,1994). Bu etkilerin en belirgin olanları istihdam ve gelirde meydana gelen artışlardır. Uluslararası turizm faaliyetleri ülkelerin ekonomik büyümesinde, ödemeler bilançosu açı̆̆ının kapatılmasında ve istihdamında önemli katkılar sağlamaktadır (Robinson, 2001:34). Birçok ülke, büyüyen turizm sektöründen işsizliğin azaltılması başta olmak üzere, birçok alanda yararlanmak istemektedirler. Çünkü beklentilere göre, turizm sektöründen elde edilen ekonomik kazanımların her geçen gün daha da artarak devam edeceği düşünülmektedir.

Turizm sektörünün gelişmesi, sürdürülebilirliği ve turizm sektöründen yeterince pay alınabilmesi için altyapı, üstyapı ve tamamlayıcı turistik yatırımlar gereklidir. Ancak sadece altyapı ve üstyapı yatırımları, fiziksel, teknolojik donanım ve ekonomik gelişmeler, hizmet kalitesini tek başına artırmak için yeterli değildir. Ayrıca sosyal üstyapı olan insan kaynağına da ihtiyaç duyulan alanlarda ve intiyaç oranında yatırım yapılması gerekmektedir (Solmaz ve Erdoğan, 2013:560). Turizm sektöründe insan kaynağına yatırım ise, ancak mesleki eğitimle mümkün olabilmektedir (Aymankuy ve Aymankuy 2013:2). Bu bilinç doğrultusunda, turizm sektöründeki kalifiye eleman ihtiyacını karşılamak amacıyla, Türkiye'de örgün ve yaygın mesleki turizm eğitimi verilmektedir. Örgün turizm eğitimi, ortaöğretim ve yükseköğretim seviyelerinde turizm eğitimi veren okullarda yapılmakta, yaygın turizm eğitimi ise resmi ya da özel kurumlar tarafından verilen kısa süreli mesleki kurslar şeklinde yapılmaktadır (Ünlüönen ve Boylu, 2005:15). Yüksek öğretim seviyesinde ise ön lisans ve lisans düzeyinde mesleki turizm eğitimi yapılmaktadır. Turizm eğitimiyle kalifiye işgücünün turizm sektörüne kazandırılması, hizmetin kalite değerinin yükseltilmesi, zaman, malzeme, işgücü tasarrufu ile verimliliğin yükseltilmesi (Ehtiyar ve Engüren, 2008:174) amaçlanmaktadır. Ancak turizm eğitimi alan öğrencilerin önemli bir bölümünün turizm sektöründe çalışmadığı bilinmektedir. Pavesic ve Brymer (1990) turizm eğitimi veren okullardan mezun olan öğrencilerin $1 / 5$ 'inin mezun olduktan sonraki yıl içinde, 1/3'ünün de takip eden 5 yıl içinde turizm sektörünü terk ettiğini, sadece \%46,7'sinin turizm sektöründe çalışmayı sürdürdüklerini; Milli Eğitim Bakanlığı Mesleki ve Teknik Eğitim Araştırma ve Geliştirme Merkezi Başkanlığı (MATARGEM), 1999-2000 yıllarını kapsayan araştırma Anadolu Otelcilik Turizm Meslek Lisesi ve Anadolu Aşçılık Meslek Lisesi mezunlarının genellikle 29 yaşından sonra turizm sektörünü terk ettiklerini ve \%31,2'sinin turizm sektöründe çalışmak istemediğini; Avcıkurt ve diğ., (2012), Balıkesir Turizm İşletmeciliği ve Otelcilik Yüksekokulu (BTiOYO) mezunlarının \%31'inin turizm sektöründe, \%69'unun diğer sektörlerde çalışmayı sürdürdüklerini tespit etmiştir.

Araştırmanın temel amacı turizm lisans öğrencilerinin turizm sektöründe çalışma eğilimlerini ortaya koymaktır. Araştırmanın bir başka amacı ise, turizm lisans öğrencilerinin demografik değişkenlerini (cinsiyet, yaş, ikamet ettiği yer, ailenin gelir durumu, kardeş sayısı, anne-babanın eğitim düzeyi, mezun olunan lise, üniversitede devam edilen bölüm, devam edilen sınıf, staj/mesleki deneyim vb.) tespit etmektir. Son olarak da tespit edilen demografik özelliklerle öğrencilerin turizm sektöründe çalışma eğilimleri arasında bir ilişki olup olmadığının belirlenmesi amaçlanmaktadır.

\section{Literatür Taraması}

Turizm eğitimi alan öğrencilerin turizm sektörüne yönelik tutumları ve kariyer planlamaları hakkında ulusal ve uluslararası birçok araştırma yapılmıştır. Özellikle son 
10 yılda çok sayıda akademisyen ve araştırmacının bu konu üzerinde yoğun olarak çalıştıkları görülmektedir. Yapılan araştırmalarda öğrencilerin turizm sektöründe kariyer yapma konusunda farklı görüşte oldukları görülmektedir. Kimileri geleceğini turizm sektöründe görmekte, kimileri kararsız, kimileri ise turizm sektöründe kesinlikle çalışmayı düşünmemektedir.

Roos (1994), Avusturalya'da turizm meslek lisesi öğrencileri üzerine yaptığı araştırmada, öğrencilerin çoğunlukla turizm sektöründen beklenti, çalışma isteği, mesleğe yönelik tutum ve ilgilerinin yüksek oranda olumlu olduğunu tespit etmiştir. Kuşluvan ve Kuşluvan (2000), Türkiye'de lisans turizm eğitimi alan öğrenciler üzerine yaptıkları araştırmada, öğrencilerin \%57'si turizm sektörünün dezavantajlarının, avantajlarından fazla olduğunu, 2/3'ünün turizm sektöründe çalışmayı düşündüğünü, sadece \%26,5'inin turizm sektörü dışındaki sektörlerde çalışmayı düşünmediği, \%56'sı erkek çocuklarının turizm eğitimi almasını ve turizm sektöründe çalışmasını istemediğini, \%72'si kız çocuklarının turizm eğitimi almasını ve turizm sektöründe çalışmasını istemediğini, katılımcıların genel olarak turizm sektöründe çalışma konusunda olumsuz tutum içinde olduklarını; benzer şekilde Kozak ve Kızılırmak (2001), önlisans turizm eğitimi alan öğrencilerinin turizm sektöründe kariyer yapma konusunda genel olarak olumsuz tutum içinde olduklarını tespit etmişlerdir. Richardson (2009), Avusturalya'da lisans turizm öğrencileri üzerine yapılan araştırmada, yukarıdaki bulguya benzer bir bulgu ortaya koyarak öğrencilerin turizm sektöründe çalışma ve geleceklerini turizm sektörüne bağlama konusunda negatif tutum içinde olduklarını belirlemiştir.

King ve diğ., (2003), Avusturalya ve Hong Kong'ta turizm ve otel işletmeciliği mezunları üzerine yaptıkları araştırmada, öğrencilerin yarısının mezun olduktan sonra 3-5 yıl içinde turizm sektörünü terk ederek başka sektörlere yöneldiklerini ortaya koymuşlardır. Walmsley (2004), İngiltere'de turizm eğitimi almış ve turizm sektöründe çalışan bireyler üzerine yaptığı araştırmada, turizm sektöründeki işlerin sezonluk ve geçici olması ve iş garantisinin olmamasından dolayı kariyer olarak düşünülmediği, turizm sektörü ile ilgili olumsuz bir tutum içinde olunduğunu tespit etmişlerdir. Jiang ve Tribe (2009), Çin'de turizm eğitimi alan öğrenciler üzerine yaptığı araştırmada, turizm sektöründeki işlerin uzun vadeli olmayan geçici işler olduğunu, bundan dolayı turizm sektöründe uzun vadeli kariyer yapmayı düşünmediklerini belirlemişlerdir.

Roney ve Öztin (2007), lisans turizm öğrencileri üzerine yaptığı araştırma, Kuşluvan ve Kuşluvan (2000) tarafından yapılan araştırmadan biraz farklılık göstermektedir. Öğrencilerin \%70,6'sı turizm sektöründe iyi paralar kazanılabileceğine, 2/3'ü turizm eğitiminin gelecekleri için iyi bir kariyer tercihi olduğunu, öğrencilerin $\% 79,3$ 'ü turizm sektöründe çalışmanın düzgün aile yaşamını olumsuz etkileyeceğini, öğrencilerden \%49,2'si turizm sektörünün avantajlarının dezavantajlarından fazla olduğunu, $\% 50,8$ ise dezavantajlarının avantajlarından daha fazla olduğunu ortaya koymuşlardır. Lu ve Adler (2009), Çin'de farklı üniversitelerin lisans öğrencileri üzerine yaptıkları araştırma, mevcut araştırmalardan farklılık göstermektedir. Bu araştırma, öğrencilerin \%68,4'ünün kariyerlerini turizm sektöründe sürdürmek istediklerini, öğrencilerin değişik konularda aldıkları eğitimin gelecekleri için çok değerli olduğuna inandıklarını ve öğrencilerden \%31,6'sının turizm sektöründe kariyerlerini sürdürmek istemediğini ortaya koymaktadır. Baltacı ve diğ., (2012), önlisans, lisans ve lisansüstü turizm eğitimi alan öğrencilerin eğitim memnuniyeti üzerine yaptıkları araştırmada, okudukları bölümü bilerek tercih edenlerin gelecek kaygılarının daha düşük, memnuniyet seviyesinin daha fazla olduğunu ve turizm sektöründe kariyer yapma konusunda daha istekli olduklarını, erkek öğrencilerin kız öğrencilere, 3. ve 4. sınıfta okuyan öğrencilerin ise 1 . ve 2.sınıfta okuyan öğrencilerine kıyasla gelecek 
kaygılarının daha yüksek olduğunu; benzer şekilde Solmaz ve Erdoğan (2013), önlisans ve lisans turizm öğrencileri üzerine yaptıkları araştırmada, öğrencilerinin başlangıçta turizm sektörünü olumlu algıladıkları, bu durumun mezuniyet sonrası olumsuza yönelebildiği, önemli bir kesiminin mezuniyetten sonra başka sektörlerde çalışmak istediği, sektörde çalışma ve turizm eğitimi alınması noktasında başkalarına tavsiyede bulunmayacaklarını, lisans öğrencilerinin önlisans öğrencilerinden daha yüksek oranda geleceklerini turizm sektöründe gördüklerini tespit etmişlerdir. Yıldız (2013), lisans turizm öğrencileri üzerine yaptığı araştırmada, bölümlerini isteyerek ve bilinçli olarak tercih eden öğrencilerin gelecek kaygılarının daha az olduğu, öğrencilerin büyük çoğunluğunun turizm sektöründe çalışmak istedikleri, staj yapan öğrencilerin, yapmayanlara kıyasla sektöre karşı daha fazla olumsuz tutum içinde olduğunu tespit etmiştir.

Unur ve Köşker (2015), turizm eğitimi alan öğrencilerin turizm sektöründe kariyer yapmaya ve turizme yönelik tutumlarını belirlemeye dönük araştırmaların özet bulgularını derledikleri araştırmada, turizm sektöründe çalışmanın genel olarak saygın olarak görülmediği, stajların çok ağır geçtiği ve staj sonrası öğrencilerin turizm sektöründen soğumaya başladığı, turizm eğitimi alan öğrencilerin genellikle turizm sektöründe kariyer yapmaya sıcak bakmadığı, hatta mezunlardan önemli bir kesimin turizm sektörü ile ilgisi olmayan işlerde çalıştığını ortaya koymuşlardır.

$\mathrm{Bu}$ araştırma, mevcut araştırmalardan farklı olarak bir bölgeyi veya birkaç üniversitede eğitim gören lisans turizm öğrencileriyle sınırlı olmayan, tam tersine Türkiye'nin 7 bölgesindeki değişik bölümlerde ve farklı sınıflarda okuyan tüm lisans turizm öğrencilerini kapsayan bir çalışmadır. Türkiye'nin her bölgesi, lisans turizm öğrenci sayısı ile doğru orantılı olarak örnekleme dahil edilmiştir. Bu yönüyle araştırmanın diğer araştırmalardan farklı ve özgün olduğu düşünülmektedir.

\section{Araştırmanın Yöntemi}

Araştırmanın temel amacı lisans turizm öğrencilerinin TSÇE yönelik tutumlarını ortaya koymaktır. Ayrıca öğrencilerin sosyo-demografik değişkenleri (cinsiyet, yaş, ikamet ettiği yer, ailenin gelir durumu, kardeş sayısı, anne-babanın eğitim düzeyi, mezun olunan lise, üniversitede devam edilen bölüm, devam edilen sınıf, staj/mesleki deneyim vb.) tespit etmek ve bu değişkenler ile TSÇE arasındaki ilişkiyi incelemektir.

Lisans turizm öğrencilerinin sosyo-demografik özelliklerinin belirlenmesi ve kimlerin turizm sektöründe çalışmayı düşündüklerinin bilinmesi başta öğrencilerin kendileri olmak üzere, üniversite tercihlerinde etkili olan psikolojik danışmanlık ve rehberlik (PDR) öğretmenleri ve aileler tarafından kullanılabilecek yeni veri ve bilgiler sağlayacaktır. Bu yeni veri ve bilgiler ise üniversiteye girişteki bölüm tercihlerinin daha bilinçli yapılmasına katkıda bulunulabilir.

Araştırmada nicel araştırma yöntemi uygulanmış ve veri toplama aracı olarak ise anket yöntemi kullanılmıştır. Lisans turizm öğrencilerin turizm mesleğini devam ettirmeye yönelik düşüncelerini değerlendirmek amacıyla Kuşluvan ve Kuşluvan (2000) tarafından yapılan "Perception and attitudes of undergraduate tourism students towards working in the tourism industry in Turkey" isimli çalışmadaki orijinali İngilizce olan ölçekten faydalanılmıştır.

Araştırma evrenini, Türkiye'de turizm lisans eğitimi almakta olan öğrenciler oluşturmaktadır. Araştırma evreninin Türkiye'nin bütün bölgelerine dağılmış olmasından dolayı, evrenin tamamına ulaşılmasının zaman ve maliyet açısından 
mümkün olamayacağı düşünüldüğünden tabakalı örnekleme yöntemi kullanılmıştır. Bu doğrultuda Türkiye'nin yedi bölgesindeki lisans turizm eğitimi veren okullar yedi kümeye ayrılmıştır. Her bölge öğrenci sayısı ile doğru orantılı olarak kümelendirilip, örnekleme dahil edilmiştir. Öğrencilerin bölgelere ve üniversitelere göre dağılımı Tablo 1 'de yer almaktadır.

Tablo 1: Türkiye'deki Lisans Turizm Öğrenci Sayıları ve Bölgesel Dağılımı

\begin{tabular}{|l|c|c|c|}
\hline Bölge & Öğrenci Sayısı & Türkiye \%'si & Uygulanan Anket Sayısı \\
\hline Marmara & 9036 & 24,4 & 196 \\
\hline Akdeniz & 7702 & 20,9 & 167 \\
\hline Ege & 7440 & 20,2 & 161 \\
\hline İç Anadolu & 7006 & 19,0 & 152 \\
\hline Karadeniz & 3930 & 10,7 & 85 \\
\hline Doğu Anadolu & 1360 & 3,7 & 29 \\
\hline Güneydoğu Anadolu & 440 & 1,1 & 10 \\
\hline TOPLAM & $\mathbf{3 6 9 1 4}$ & $\mathbf{1 0 0}$ & $\mathbf{8 0 0}$ \\
\hline
\end{tabular}

Kaynak: ÖSYM 2015 Yüksek Öğretim Programları ve Kontenjanları Klavuzu; YÖK 2016 lisans öğrenci sayısı atlasından yararlanılarak hazırlanmıştır.

Anket verileri 28.12.2015-15.03.2016 tarihleri arasında toplanmıştır. Toplamda 800 anket değerlendirmeye alınmıştır. Değerlendirmeye alınan anketlerin toplandığı üniversite ve bölümleri ise; Balıkesir Üniversitesi Turizm Fakültesi: 196, Mersin Üniversitesi Turizm Fakültesi: 167, Adnan Menderes Üniversitesi Turizm Fakültesi: 161, Gazi Üniversitesi Turizm Fakültesi: 152, Düzce Üniversitesi Akçakoca Turizm İşletmeciliği ve Otelcilik Yüksekokulu: 75, Atatürk Üniversitesi Turizm Fakültesi: 29, Gaziantep Üniversitesi Güzel Sanatlar Fakültesi Gastronomi ve Mutfak Sanatları Bölümü: 10'dur. TSÇE ölçeğinin güvenilirlik analizi Cronbach Alpha katsayısı 0,951 olarak, KMO örneklem yeterliliği 0,940 olarak hesaplanmıştır.

\section{Bulgular}

Tablo 2'de katılımcıların demografik özelliklerine ilişkin bulgular yer almakta ve özetlenmektedir. Araştırmaya katılan 800 lisans turizm öğrencisinin \%51,1 kadınlardan, $\% 48,9$ erkeklerden oluşmaktadır. Öğrencilerin \%49,4'ünün ailelerinin toplam gelirinin 02000 TL arasında, \%37,3'ünün 2001-4000 TL arasında ve yalnızca \%3,9'unun 6000TL ve üstü olduğu tespit edilmiştir.

Katılımcıların eğitim aldıkları lise türlerine bakıldığında, \%40,4'ı düz lise, \%24,1'i Anadolu lisesi, \%16'sı Anadolu turizm ve otelcilik lisesi, \%13,3'ü diğer lise grupları, $\% 4,8$ 'i diğer turizm meslek liseleri, \%08'i imam hatip lisesi, \%06'sı sosyal bilimler lisesi ve $\% 01$ 'i fen lisesi mezunlarından oluştuğu görülmektedir.

Araştırmaya katılan öğrencilerin annelerinin $\% 70,3$ 'ünün ortaokul ve daha alt düzeyde yalnızca \%8,3'ünün üniversite ve üstü düzeyde; babalarının ise, \%56,1'inin ortaokul ve daha alt düzeyde yalnızca \%14,7'sinin üniversite ve üstü düzeyde eğitim aldıkları görülmektedir. Öğrencilerin \%64,8'i şehirde (il, ilçe), \%35,2 kırsalda (köy, belde) ikamet etmektedir.

Katılımcıların \%81,6'sı 19-23 yaş aralığındadır. 19 yaşından küçük katılımcıların oranı \%6,0, 23 yaşından büyük katılımcıların oranı \%12,4, 26 ve üstü yaş grubunun oranı ise sadece \%2,8'dir. Bu bulgu bir taraftan öğrencilerinin yaş olarak turizm sektörünün genel işgücü profili için uygun olduğunu ortaya koyarken diğer taraftan öğrencilerin lisans turizm eğitim kurumlarından ağırlıklı olarak normal sürelerinde mezun oldukları şeklinde de yorumlanabilir. 
Tablo 2: Demografik Bulgular

\begin{tabular}{|c|c|c|c|c|c|}
\hline & Frekans & Yüzde (\%) & & Frekans & Yüzde (\%) \\
\hline \multicolumn{3}{|l|}{ Cinsiyet } & \multicolumn{3}{|c|}{ Babanın Eğitim Seviyesi } \\
\hline Kadın & 409 & 51,1 & Okur-yazar Değil & 10 & 1,3 \\
\hline Erkek & 391 & 48,9 & İlkokul & 258 & 32,3 \\
\hline Toplam & 800 & 100,0 & Ortaokul & 180 & 22,5 \\
\hline \multicolumn{2}{|l|}{ Yaş } & & Lise & 235 & 29,4 \\
\hline 18 & 48 & 6,0 & Ön lisans & 22 & 2,8 \\
\hline 19 & 101 & 12,6 & Lisans & 85 & 10,6 \\
\hline 20 & 171 & 21,4 & Lisansüstü & 10 & 1,3 \\
\hline 21 & 143 & 17,9 & Toplam & 800 & 100,0 \\
\hline 22 & 129 & 16,1 & \multicolumn{3}{|c|}{ Annenin Eğitim Seviyesi } \\
\hline 23 & 109 & 13,6 & Okur-yazar Değil & 56 & 7,0 \\
\hline 24 & 48 & 6,0 & İlkokul & 343 & 42,9 \\
\hline 25 & 29 & 3,6 & Ortaokul & 163 & 20,4 \\
\hline 26 ve üstü & 22 & 2,8 & Lise & 172 & 21,5 \\
\hline Toplam & 800 & 100,0 & Ön lisans & 9 & 1,1 \\
\hline \multicolumn{3}{|c|}{ Aile Üyelerinin Toplam Aylık Geliri } & Lisans & 46 & 5,8 \\
\hline $0-1300$ & 128 & 16,0 & Lisansüstü & 11 & 1,4 \\
\hline $1301-2000$ & 267 & 33,4 & Toplam & 800 & 100,0 \\
\hline $2001-3000$ & 195 & 24,4 & \multicolumn{3}{|c|}{ Ünv. Kazanmadan İkamet Yeri } \\
\hline $3001-4000$ & 104 & 13,0 & Köy & 123 & $\overline{15,4}$ \\
\hline $4001-5000$ & 41 & 5,1 & Belde & 159 & 19,9 \\
\hline $5001-6000$ & 34 & 4,3 & İlçe Merkezi & 248 & 31,0 \\
\hline 6001 ve üstü & 31 & 3,9 & $\mathrm{III}^{3}$ & 270 & 33,8 \\
\hline Toplam & 800 & 100,0 & Toplam & 800 & 100,0 \\
\hline \multicolumn{3}{|l|}{ Mezun Olunan Lise } & \multicolumn{3}{|l|}{ Kardeş Sayısı } \\
\hline Düz Lise & 323 & 40,4 & 1 & 78 & 9,8 \\
\hline Anadolu Lisesi & 193 & 24,1 & 2 & 329 & 41,1 \\
\hline A.Turizm ve Otelcilik & 128 & 16,0 & 3 & 237 & 29,6 \\
\hline Diğerleri & 106 & 13,3 & 4 & 73 & 9,1 \\
\hline $\begin{array}{l}\text { Diğer Turizm Meslek } \\
\text { L. }\end{array}$ & 38 & 4,8 & 5 & 33 & 4,1 \\
\hline İmam Hatip Lisesi & 6 & ,8 & 6 & 18 & 2,3 \\
\hline $\begin{array}{l}\text { Sosyal Bilimler } \\
\text { Lisesi }\end{array}$ & 5 & 6 & 7 & 10 & 1,3 \\
\hline Fen Lisesi & 1 & 1 & 8 & 8 & 1,0 \\
\hline Toplam & 800 & 100,0 & 9 & 6 & ,8 \\
\hline & & & 10 ve Üstü & 8 & 1,0 \\
\hline & & & Toplam & 800 & 100,0 \\
\hline
\end{tabular}

Katılımcılardan \%80,5'inin 1, 2 veya 3 kardeşli ailelerin çocukları olduğu görülmektedir. \%9,8'inin 1, \%41,1'inin 2, \%29,6'sının 3 kardeşi vardır. Kardeş sayısı 5 'ten fazla olan katılımcıların genel toplamı sadece $\% 6,4$ oranındadır.

\subsection{Katılımcıların Okudukları Bölümlere İlişkin Bulgular}

Tablo 3'te katılımcıların okudukları bölüme ilişkin bulgular yer almaktadır. Katılımcıların \%33,8'i Turizm İşletmeciliği, \%16,1'i Konaklama İşletmeciliği, \%15,4'i Seyahat İşletmeciliği, \%15,1'i Turizm Rehberliği, \%8,9'u Gastronomi ve Mutfak Sanatları, \%6,8'i Yiyecek İçecek İşletmeciliği ve \%4'ü Rekreasyon Yönetimi bölümü öğrencilerinden oluşmaktadır. Katılımcıların \%25,5'i 1. sınıf, \%26,1'i 2. sınıf, \%25,1'i 3. sınıf ve $\% 23,3$ 'ü 4. sınıf öğrencilerinden oluşmaktadır.

Araştırmaya katılan öğrencilerin $\% 72,4$ 'ü eğitimini devam ettirdikleri bölüme isteyerek geldiğini, \%27,6'sı ise istemeyerek geldiğini belirtmektedir. Katılımcılardan $\% 51$ 'i okudukları bölümün kendi tercihi olduğunu, $\% 17,1$ 'i diğer nedenlerle tercih ettiklerini, \%11,3'ü rehber öğretmenlerin etkili olduğunu, \%11,1'i ailesinin etkisiyle 
tercih ettiğini, \%9,1 arkadaş ve akrabalarından etkilenerek tercihte bulunduklarını ifade etmektedirler.

Tablo 3: Katılımcıların Okudukları Bölümlere İlişkin Bulgular

\begin{tabular}{|c|c|c|c|c|c|}
\hline & Frekans & Yüzde (\%) & & Frekans & Yüzde (\%) \\
\hline \multicolumn{3}{|l|}{ Okunan Bölüm } & \multicolumn{3}{|c|}{ Bölümün Tercih Sırası } \\
\hline Turizm İşletmeciliği & 270 & 33,8 & 1. & 151 & 18,9 \\
\hline Konaklama Işletmeciliği & 129 & 16,1 & 2. & 59 & 7,4 \\
\hline Seyahat İşletmeciliği & 123 & 15,4 & 3. & 78 & 9,8 \\
\hline Turizm Rehberliği & 121 & 15,1 & 4. & 51 & 6,4 \\
\hline $\begin{array}{l}\text { Gastronomi ve Mutfak } \\
\text { Sanatları }\end{array}$ & 71 & 8,9 & 5. & 49 & 6,1 \\
\hline Yiyecek İçecek İşletmeciliği & 54 & 6,8 & 6. & 26 & 3,3 \\
\hline Rekreasyon Yönetimi & 32 & 4,0 & 7. & 47 & 5,9 \\
\hline \multirow[t]{2}{*}{ Toplam } & 800 & 100,0 & 8. & 24 & 3,0 \\
\hline & & & 9. & 23 & 2,9 \\
\hline \multicolumn{3}{|l|}{ Bölüme İsteyerek mi Gelindi? } & 10. & 18 & 2,3 \\
\hline Evet & 579 & 72,4 & 11. & 36 & 4,5 \\
\hline Hayır & 221 & 27,6 & 12. & 23 & 2,9 \\
\hline \multirow[t]{2}{*}{ Toplam } & 800 & 100,0 & 13. & 40 & 5,0 \\
\hline & & & 14. & 18 & 2,3 \\
\hline \multicolumn{3}{|c|}{ Bölüm Tercihini Kim Etkiledi? } & 15. & 19 & 2,4 \\
\hline Kendi Tercihim & 411 & 51,4 & 16. & 17 & 2,1 \\
\hline Diğerleri & 137 & 17,1 & 17. & 18 & 2,3 \\
\hline Rehber Öğretmenler & 90 & 11,3 & 18. & 11 & 1,4 \\
\hline Ailem & 89 & 11,1 & 19. & 10 & 1,3 \\
\hline Arkadaşlar/Akrabalar & 73 & 9,1 & 20. & 10 & 1,3 \\
\hline \multirow[t]{2}{*}{ Toplam } & 800 & 100,0 & 21. & 16 & 2,0 \\
\hline & & & 22. & 4 &, 5 \\
\hline \multicolumn{3}{|l|}{ Kaçıncı Sınıf Öğrencisi } & 23. & 8 & 1,0 \\
\hline 1. Sinıf & 204 & 25,5 & 24. & 9 & 1,1 \\
\hline 2. Sinıf & 209 & 26,1 & 25. & 6 & , 8 \\
\hline 3. Sınıf & 201 & 25,1 & 26. & 6 & ,8 \\
\hline 4. Sinıf & 186 & 23,3 & 27. & 5 & 6 \\
\hline \multirow[t]{4}{*}{ Toplam } & 800 & 100,0 & 28. & 3 &, 4 \\
\hline & & & 29. & 2 & ,3 \\
\hline & & & 30. & 13 & 1,6 \\
\hline & & & Toplam & 800 & 100,0 \\
\hline
\end{tabular}

Katılımcıların okudukları bölümü tercih sırası 1 . ile 30 . tercih arasında değişmektedir. Katılımcılardan \%18,9'u bölümünü 1. sırada, \%7,4'ü 2. sırada, \%9,8'u 3. sırada tercih etmiştir. Katılımcıların $\% 65,75$ 'i okuduğu bölümü $1 .-10$. , \%25,25'i 11 .20., \%9'u 21.- 30. sıralar arasında tercih etmiştir.

\subsection{Staj/Mesleki Deneyimine İlişkin Demografik Bulgular}

Tablo 4'te katılımcıların staj/mesleki deneyimine ilişkin bulgular yer almaktadır. Katılımcıların \%49,6'sı staj/mesleki deneyiminin olduğunu, \%50,4'ü staj/mesleki deneyiminin olmadığını belirtmektedir. Staj/mesleki deneyimi olan katılımcıların, mesleki deneyimi yaşadığı yerler; \%70,8 otel, \%15,6 seyahat acentesi, \%5,8 diğer kurumlar, \%5 tatil köyü, \%3'ü turizm işletmeciliği belgesi olan restoranlar olarak belirtmişlerdir. Staj/mesleki deneyime sahip olan lisans öğrencilerinin büyük çoğunluğunun staj/mesleki deneyimin genellikle 5 yıldızlı otel, A grubu seyahat acenteleri ve 4 yıldızlı otellerde yaşandığı tespit edilmiştir. Bu bulgu katılımcıların çoğunluğunun turizm işletmeciliği ve konaklama işletmeciliği bölümlerinde okumaları ile açıklanabilir. 
Tablo 4: Staj/Mesleki Deneyimine İlişkin Bulgular

\begin{tabular}{|c|c|c|c|c|c|}
\hline & Frekans & Yüzde (\%) & & Frekans & Yüzde (\%) \\
\hline \multicolumn{2}{|c|}{ Staj Deneyimi } & & \multicolumn{3}{|c|}{ Staj Dahil Mesleki Deneyim Süresi } \\
\hline Evet & 397 & 49,6 & $1 \mathrm{Ay}$ & 4 & 1,0 \\
\hline Hayır & 403 & 50,4 & $2 \mathrm{Ay}$ & 11 & 3,8 \\
\hline Toplam & 800 & 100,0 & $3 \mathrm{Ay}$ & 69 & 17,4 \\
\hline & & & $4 \mathrm{Ay}$ & 45 & 11,3 \\
\hline \multicolumn{2}{|c|}{ Nerede Staj Yaptı } & & $5 \mathrm{Ay}$ & 7 & 1,8 \\
\hline Otel & 281 & 70,8 & $6 \mathrm{Ay}$ & 37 & 9,3 \\
\hline Seyahat Acentesi & 62 & 15,6 & 9 Ay & 21 & 5,3 \\
\hline Diğerleri & 23 & 5,8 & $1 \mathrm{YII}$ & 22 & 5,5 \\
\hline Tatil Köyü & 20 & 5,0 & $1 \mathrm{Y}$ II $3 \mathrm{Ay}$ & 25 & 6,3 \\
\hline Restoran & 11 & 2,8 & $1 Y_{\imath} \mid \mathrm{Ay}$ & 13 & 3,3 \\
\hline Toplam & 397 & 100,0 & $2 Y_{I I}$ & 22 & 5,5 \\
\hline & & & 2 Yı 6 Ay & 33 & 8,3 \\
\hline \multicolumn{3}{|c|}{ Staj Yapılan İşletmenin Yıldız/Grup/Sınıfı } & 2 Yıl $9 \mathrm{Ay}$ & 6 & 1,5 \\
\hline 3 Yıldızıı Otel & 7 & 1,8 & $3 Y_{I I}$ & 14 & 3,5 \\
\hline 4 Yıldızlı Otel & 44 & 11,1 & 3 Yıl 6 Ay & 16 & 4,0 \\
\hline 5 Yıldızlı Otel & 221 & 55,7 & $4 \mathrm{YII}$ & 11 & 2,8 \\
\hline 7 Yıldızlı Otel & 8 & 2,0 & 4 Yıl 6Ay & 6 & 1,5 \\
\hline $\begin{array}{l}\text { A Grubu Seyahat } \\
\text { Act. }\end{array}$ & 50 & 12,6 & $5 \mathrm{Yll}$ & 15 & 3,8 \\
\hline $\begin{array}{l}\text { B Grubu Seyahat } \\
\text { Act. }\end{array}$ & 6 & 1,5 & $6 \mathrm{YIl}$ & 13 & 3,3 \\
\hline $\begin{array}{l}\text { C Grubu Seyahat } \\
\text { A. }\end{array}$ & 4 & 1,0 & $7 \mathrm{YIl}$ & 5 & 1,3 \\
\hline 1. Sınıf Tatil Köyü & 18 & 4,5 & $8 \mathrm{YIl}$ & 2 &, 5 \\
\hline 2. Sınıf Tatil Köyü & 3 & ,8 & Toplam & 397 & 100,0 \\
\hline $\begin{array}{l}\text { Tur. İşl. Bel. } \\
\text { Restoran }\end{array}$ & 12 & 3,0 & \multicolumn{3}{|c|}{ Stajda Müşteri ile İletişim \%'si } \\
\hline Diğerleri & 24 & 6,0 & $\% 0$ & 11 & 2,8 \\
\hline Toplam & 397 & 100,0 & $\% 1$ & 22 & 5,5 \\
\hline & & & $\% 5$ & 31 & 7,8 \\
\hline \multicolumn{3}{|c|}{ Staj Yapılan Departman/Birim } & $\% 10$ & 28 & 7,0 \\
\hline Yiyecek İçecek & 100 & 25,2 & $\% 20$ & 21 & 5,3 \\
\hline Önbüro & 78 & 19,6 & $\% 25$ & 15 & 3,8 \\
\hline Mutfak & 72 & 18,1 & $\% 30$ & 11 & 2,8 \\
\hline Diğerleri & 42 & 10,6 & $\% 40$ & 15 & 3,8 \\
\hline $\begin{array}{l}\text { Sey. Act. } \\
\text { Operasyon }\end{array}$ & 25 & 6,3 & $\% 50$ & 26 & 6,5 \\
\hline Kat Hizmetleri & 23 & 5,8 & $\% 60$ & 28 & 7,0 \\
\hline Sey. Act. Biletleme & 20 & 5,0 & $\% 70$ & 25 & 6,3 \\
\hline Muhasebe & 17 & 4,3 & $\% 75$ & 44 & 5,5 \\
\hline Sey.Act. Pazarlama & 16 & 4,0 & $\% 80$ & 49 & 12,3 \\
\hline Sey.Act. Rehberlik & 2 &, 5 & $\% 90$ & 55 & 13,6 \\
\hline Sey. Act. Transfer & 2 &, 5 & $\% 95$ & 17 & 4,3 \\
\hline Toplam & 397 & 100,0 & Toplam & 397 & 100,0 \\
\hline
\end{tabular}

Staj/mesleki deneyimi olan katılımcıların \%25,2'si yiyecek içecek, \%19,6'sı önbüro, \%18,1'i mutfak, \%10,6'sı diğer, \%6,3'ü seyahat acentesi operasyon, \%5,8'i kat hizmetleri, $\% 5$ 'i seyahat acentesi biletleme, $\% 4,3$ 'ü muhasebe, geriye kalan $\% 5$ ise seyahat acentesinin pazarlama, rehberlik ve transfer gibi birimlerinde mesleki deneyim yaşadıklarını belirtmişlerdir. Bu anlamda, katılımcıların staj/mesleki deneyimlerini daha çok yiyecek-içecek, önbüro ve mutfak gibi departmanlarda yaşadığı söylenebilir.

Staj/mesleki deneyimi olan katılımcıların mesleki deneyim sürelerinin en az 1 ay (\%1) en fazla 8 yıl $(\% 0,5)$ olduğu görülmektedir. Katılımcılardan \%17,4'ünün staj/mesleki deneyim süresinin 3 ay ve \%11,3'nün 4 ay olduğu tespit edilmiştir. Katılımcıların \%51,1'inin staj/mesleki deneyim süresi 1 yıldan daha fazla olarak ortaya 
çıkmıştır. Staj/mesleki deneyim süresi kısa olan katılımcıların staj/mesleki deneyimlerini ilk kez zorunlu staj sonucu yaşadıkları; staj/mesleki deneyim süresi uzun olan katılımcıların bir kısmının turizm liselerinden geldikleri ve dolayısıyla turizm sektörünün avantaj ve dezavantajlarını bilerek, bilinçli bir şekilde turizm bölümünü seçen öğrenciler olduğu; bir kısmının ise her yaz çalışan ya da hem çalışıp hem eğitimini sürdüren üst sınıf öğrencileri olduğu düşünülmektedir. Her ne kadar oran vermek mümkün olmasa da öğrencilerin \%19,2'sinin 3 yıl ve daha fazla sektörel deneyimleri olduğunu söylemesi öğrencilerin bir kısmının ise üniversiteye gelmeden önce turizm sektöründe çalıştığı şeklinde yorumlanabilir.

Staj/mesleki deneyimi olan katılımcıların müşteri ile iletişim yüzdesinin (\%) en az $\% 1$, en fazla \%95 olduğu görülmektedir. Bu anlamda önbüro, yiyecek içecek, seyahat acentesinin pazarlama, biletleme ve rehberlik gibi birimlerde müşteri ile iletişimin daha fazla olduğu, muhasebe, kat hizmetleri ve mutfak gibi birimlerde müşteri ile iletişimin daha az olduğu düşünülmektedir.

\subsection{Katılımcıların TSÇE'ne Yönelik Tutumları}

Katılımcıların TSÇE yönelik tutumlarını ifade eden ölçek maddeleri Tablo 5'te yer almaktadır. Katılımcıların TSÇE'ne yönelik tutumları genel olarak değerlendirildiğinde; katılımcılar 3,23 ortalama ile turizm sektöründe çalışmanın dezavantajlarının, avantajlarından ağır bastığını düşünmekle birlikte, 3,42 ortalama ile turizmi meslek olanı olarak seçtiklerine memnun oldukları, 3,19 ortalama ile mesleki geleceğini turizm sektöründe gördükleri, 2,47 ortalama ile turizm sektörü dışında çalışmayı düşünmedikleri görülmektedir. Bununla birlikte katılımcıların ortalamanın üzerinde bir oranla kız ve erkek çocuklarının turizm eğitimi almasını ve turizm sektöründe çalışmasını istemedikleri, ancak ortalamanın üzerinde $(3,13)$ bir oranla başkalarına tavsiye etmeyi düşündükleri ortaya çıkmıştır.

Tablo 5: Katılımcıların TSÇE Yönelik Tutumları

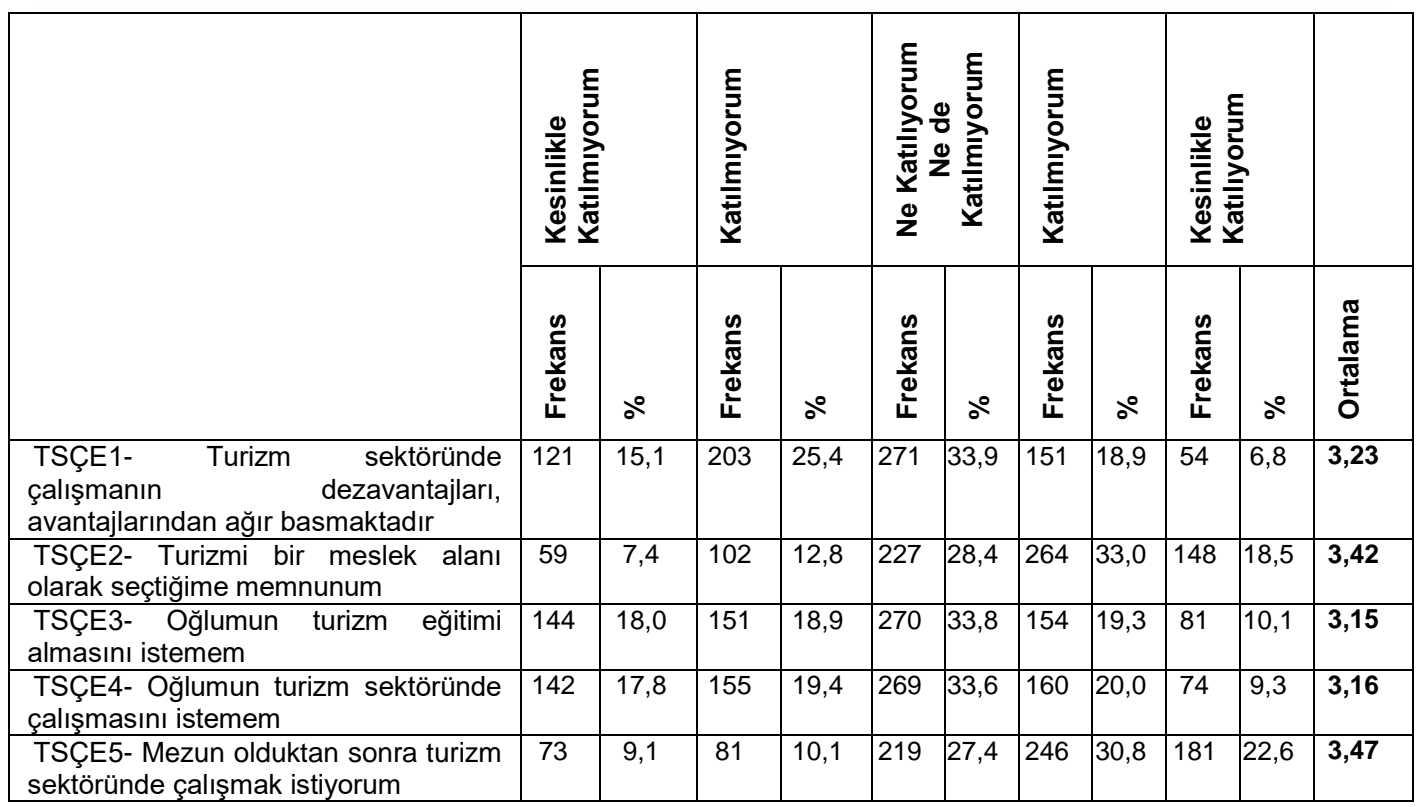


Tablo 5'in Devamı

\begin{tabular}{|c|c|c|c|c|c|c|c|c|c|c|c|}
\hline $\begin{array}{l}\text { TSÇE6- Turizm sektöründe çalışmak } \\
\text { için büyük çaba sarf etmeyeceğim }\end{array}$ & 82 & 10,3 & 167 & 20,9 & 239 & 29,9 & 201 & 25,1 & 111 & 13,9 & 2,88 \\
\hline $\begin{array}{l}\text { TSÇE7- Mezun olduktan sonra turizm } \\
\text { sektöründe herhangi bir iş yaparım }\end{array}$ & 87 & 10,9 & 133 & 16,6 & 287 & 35,9 & 211 & 26,4 & 82 & 10,3 & 3,08 \\
\hline 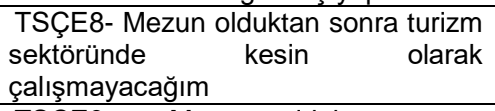 & 216 & 27,0 & 225 & 28,1 & 279 & 34,9 & 42 & 5,3 & 38 & 4,8 & 2,32 \\
\hline $\begin{array}{l}\text { TSÇE9- Mezun olduktan sonra } \\
\text { yönetici veya departman yöneticisi } \\
\text { olmak şartıyla turizm sektöründe } \\
\text { çalışırım }\end{array}$ & 41 & 5,1 & 116 & 14,5 & 245 & 30,6 & 262 & 32,8 & 139 & 17,0 & 3,42 \\
\hline $\begin{array}{l}\text { TSÇE10- Birinci sınıfta okuyan turizm } \\
\text { öğrencilerine üniversite sınavlarına } \\
\text { hazırlanıp başka bir bölüm } \\
\text { okumalarını öneririm }\end{array}$ & 140 & 17,5 & 182 & 22,8 & 241 & 30,1 & 122 & 15,3 & 115 & 14,4 & 2,86 \\
\hline $\begin{array}{l}\text { TSÇE11- Turizmi kariyer olarak } \\
\text { seçmem büyük bir hata idi }\end{array}$ & 204 & 25,5 & 239 & 29,9 & 223 & 27,9 & 62 & 7,8 & 72 & 9,0 & 2,44 \\
\hline $\begin{array}{l}\text { TSÇE12- Kızımın turizm eğitimi } \\
\text { almasını istemem }\end{array}$ & 89 & 11,1 & 114 & 14,3 & 213 & 26,6 & 189 & 23,6 & 195 & 24,4 & 3,55 \\
\hline $\begin{array}{l}\text { TSÇE13- Kızımın turizm sektöründe } \\
\text { çalı̧̧masını istemem }\end{array}$ & 82 & 10,3 & 111 & 13,9 & 212 & 26,5 & 182 & 22,8 & 213 & 26,6 & 3,41 \\
\hline $\begin{array}{l}\text { TSÇE14- } \\
\text { purçazm sektörünün bir } \\
\text { parası olmak güzel/hoş olduğu için } \\
\text { arkadaş ve akrabalarıma tavsiye } \\
\text { ederim }\end{array}$ & 82 & 10,3 & 116 & 14,5 & 305 & 38,1 & 209 & 26,1 & 88 & 11,0 & 3,13 \\
\hline $\begin{array}{l}\text { TSÇE15- Turizm sektöründe sadece } \\
\text { yüksek ücretli işlerde çalışırım }\end{array}$ & 37 & 4,6 & 117 & 14,6 & 282 & 35,3 & 254 & 31,8 & 110 & 13,8 & 3,35 \\
\hline $\begin{array}{l}\text { TSÇE16- Turizm sektörü dışında } \\
\text { başka bir sektörde çalışmayı } \\
\text { planlamıyorum }\end{array}$ & 183 & 22,9 & 218 & 27,3 & 273 & 34,1 & 85 & 10,6 & 41 & 5,1 & 2,47 \\
\hline $\begin{array}{l}\text { TSÇE17- Mesleki geleceğimi turizm } \\
\text { sektöründe görüyorum }\end{array}$ & 90 & 11,3 & 115 & 14,4 & 277 & 34,6 & 187 & 23,4 & 131 & \begin{tabular}{|l|}
16,4 \\
\end{tabular} & 3,19 \\
\hline
\end{tabular}

\subsection{Kişisel Özellik Değişkenleri İle TSÇE Arasındaki İlişkiye Yönelik Bulgular}

Cinsiyetin, TSÇE'ne yönelik tutumlar üzerinde anlamlı bir etkisi olup olmadığının belirlenmesi amacıyla uygulanan bağımsız örneklem t-testi sonuçlarına göre, kadınların TSÇE'ne yönelik tutumları (varyanslar homojen, $p=0,366$, serbestlik derecesi $=798, t=$, çift yönlü $p=0,000$ ) erkeklere kıyasla anlamlı bir şekilde yüksek değerlere sahiptir. Bu sonucun ortaya çıkmasının, kadınların yaradılışları gereği erkeklerden daha yardımsever, özverili, fedakâr ve sabırlı olmalarına bağlı olduğu düşünülmektedir.

Katılımcının okuduğu bölümü isteyerek seçmesi değişkeninin TSÇE'ne yönelik tutumlar üzerinde anlamlı bir etkisi olup olmadığının belirlenmesi amacıyla uygulanan bağımsız örneklem t-testi sonuçlarına göre, okuduğu bölümü isteyerek seçen katılımcıların TSÇE'ne yönelik tutumları (varyanslar homojen değil, $p=0,021$ serbestlik derecesi $=798, t=15,583$ çift yönlü $p=0,000$ ) okuduğu bölümü istemeyerek seçenlere kıyasla anlamlı bir şekilde yüksek değerlere sahiptir. Bu sonuç, bireyin mesleğini isteyerek bilinçli olarak seçmesinin, o mesleği devam ettirmede önemli bir faktör olduğunu düşündürmektedir.

Staj/mesleki deneyim değişkeninin TSÇE'ne yönelik tutumlar üzerinde anlamlı bir etkisinin olup olmadığını tespit edebilmek amacıyla uygulanan bağımsız örneklem ttesti sonuçlarına göre, staj/mesleki deneyimin TSÇE'ne yönelik tutumlar üzerinde staj/mesleki deneyimi olmayanlar (varyanslar homojen değil, $p=0,004$, serbestlik derecesi $=784, t=-4,294$, çift yönlü $p=0,000$ ) staj/mesleki deneyimi olanlara kıyasla 
anlamlı bir şekilde yüksek değerlere sahiptir. Bu sonuç, lisans turizm öğrencilerinin turizm sektöründe staj/mesleki deneyimi yaşamadan önce kariyer yapma konusunda istekli oldukları, ancak turizm sektörünün çalışma koşullarını, yapısını ve sektörün kendine has sorunlarını gördükçe, turizm sektöründe kariyer yapma düşüncelerinin olumsuz yönde değiştiği şeklinde yorumlanabilir.

Yaşın TSÇE'ne yönelik tutumlar üzerinde anlamlı bir etkisinin bulunup bulunmadığının test edilmesi amacıyla uygulanan tek yönlü ANOVA testi sonuçları, tüm yaş gruplarının TSÇE ortalamalarının eşit olmadığını ve dolayısı ile yaşın TSÇE'ne yönelik tutumlar üzerinde anlamlı bir etkisinin bulunduğunu göstermektedir (varyanslar homojen değil, Welch's $F=6,652, p=0,001$ ). TSÇE ortalamalarında hangi yaş grubunun farklılık gösterdiğinin belirlenmesi amacıyla yapılan Games-Howell Post-Hoc testi sonuçlarına göre ise, 21 yaşın altındakiler, 21 yaş ve üstündekilere göre daha yüksek TSÇE ortalamasına sahiptir.

Okumakta olduğu bölümün TSÇE'ne yönelik tutumlar üzerinde anlamlı bir etkisinin bulunup bulunmadığının test edilmesi amacıyla uygulanan tek yönlü ANOVA testi sonuçları, okumakta olduğu bölüm gruplarının TSÇE ortalamalarının eşit olmadığını ve dolayısı ile okumakta olduğu bölüm gruplarının TSÇE üzerinde anlamlı bir etkisinin olduğunu göstermektedir (varyanslar homojen, $F=3,732, p=0,001$ ). TSÇE ortalamalarında hangi bölüm grubunun farklılık gösterdiğinin belirlenmesi amacıyla yapılan Gabriel Post-Hoc testi sonuçlarına göre ise, turizm rehberliği bölümü diğer tüm bölümlere göre daha yüksek TSÇE'ne yönelik tutumlara sahiptir. Diğer bölümlerin TSÇE'e yönelik tutum ortalamaları aynıdır.

Okumakta olduğu bölümü seçmede kimlerin etkili olduğunun TSÇE'ne yönelik tutumlar üzerinde anlamlı bir etkisinin bulunup bulunmadığının test edilmesi amacıyla uygulanan tek yönlü ANOVA testi sonuçları, okumakta olduğu bölümü seçmede kimlerin etkili olduğu gruplarının TSÇE ortalamalarının eşit olmadığını ve dolayısı ile okumakta olduğu bölümü seçmede kimlerin etkili olduğu gruplarının TSÇE üzerinde anlamlı bir etkisinin olduğunu göstermektedir (varyanslar homojen değil, Welch's $F=47,591, \quad p=0,001)$. TSÇE ortalamalarında hangi bölüm grubunun farklılık gösterdiğinin belirlenmesi amacıyla yapılan Games-Howell Post-Hoc testi sonuçlarına göre ise, TSÇE'ne yönelik tutumları en yüksek olanlar, okuduğu bölümünü kendileri tercih edenlerdir. Ardından aile ve arkadaş/akraba etkisi ile tercih edenler gelmektedir. TSÇE'ne yönelik tutumları en düşük olanlar ise rehber öğretmenler ve diğer sebeplerden dolayı okuduğu bölümü tercih edenlerdir.

Okuduğu bölümü tercih sırasının TSÇE'ne yönelik tutumlar üzerinde anlamlı bir etkisinin bulunup bulunmadığının test edilmesi amacıyla uygulanan tek yönlü ANOVA testi sonuçları, okumakta olduğu bölümü tercih sırası gruplarının TSÇE ortalamalarının eşit olmadığını ve dolayısı ile okumakta olduğu bölümü tercih sırası gruplarının TSÇE üzerinde anlamlı bir etkisinin olduğunu göstermektedir (varyanslar homojen, $F=6,732, \quad p=0,001)$. TSÇE ortalamalarında hangi bölüm grubunun farklılık gösterdiğinin belirlenmesi amacıyla yapılan Gabriel Post-Hoc testi sonuçlarına göre ise, okumakta olduğu bölümü 12. tercihinden daha önce tercih edenlerin 12. den sonra tercih edenlere göre daha yüksek TSÇE'e yönelik tutumlara sahiptir

Devam etmekte olduğu sınıfın TSÇE'ne yönelik tutumlar üzerinde anlamlı bir etkisinin bulunup bulunmadığının test edilmesi amacıyla uygulanan tek yönlü ANOVA testi sonuçları, devam etmekte olduğu sınıf gruplarının TSÇE ortalamalarının eşit olmadığını ve dolayısı ile devam etmekte olduğu sınıf gruplarının TSÇE'ne yönelik 
tutumlar üzerinde anlamlı bir etkisinin olduğunu göstermektedir (varyanslar homojen değil, Welch's $F=15,285, p=0,001$ ).

Staj/mesleki deneyim yaşanan işletmenin yıldızı, grubu veya sınıfının TSÇE'ne yönelik tutumlar üzerinde anlamlı bir etkisinin bulunup bulunmadığının (staj/mesleki deneyim yaşanan işletmenin yıldızı, grubu veya sınıfı gruplarının TSÇE ortalamalarının anlamlı ölçüde farklılaşıp farklılaşmadığının) test edilmesi amacıyla uygulanan tek yönlü ANOVA testi sonuçları staj/mesleki deneyim yaşanan işletmenin yıldızı, grubu veya sınıfı gruplarının TSÇE ortalamalarının eşit olmadığını ve dolayısı ile staj/mesleki deneyim yaşanan işletmenin yıldızı, grubu veya sınıfı gruplarının TSÇE'ne yönelik tutumlar üzerinde anlamlı bir etkisinin olduğunu göstermektedir (varyanslar homojen, $F=1,430, p=0,165)$. TSÇE ortalamalarında hangi yıldız, grub veya sınıf grubunun farklılık gösterdiğinin belirlenmesi amacıyla yapılan Gabriel Post-Hoc testi sonuçlarına göre ise, 7 yıldızlı otellerde staj/mesleki deneyim yaşayanlar, diğerlerine göre daha yüksek TSÇE'ne sahip iken, 7 yıldız otel dışındakilerin TSÇE ortalamaları ise aynıdır.

Mezun olunan lisenin, aile üyelerinin aylık gelirinin, Üniversiteye başlamadan önce, ikamet edilen yerin, annenin ve babanın eğitim durumunun, kardeş sayısının, stajın/mesleki deneyimin süresinin, staj/mesleki deneyim yaşanan işletme grubunun veya departmanın ve staj/mesleki deneyim sırasında müşteri ile birebir iletişim yüzdesinin (\%) TSÇE'ne yönelik tutumlar üzerinde anlamlı bir etkisinin bulunmadığı belirlenmiştir.

\section{Sonuç}

Araştırmada kadın erkek dağılımının birbirine yakın olması, Türkiye'nin her bölgesinden lisans turizm eğitimi veren her bölümden öğrencinin olması ve her sınıftan birbirine yakın katılımcının yer alması bulguların Türkiye'deki lisans turizm eğitiminin genelini yansıtması açısından, yani sonuçların genellenebilirliği açısından önemli olduğu düşünülmektedir.

Araştırmadaki kadın $(\% 51,1)$ ve erkek $(\% 48,9)$ dağılım oranları ile 2015 yılı verilerine göre Türkiye deki kadın $(\% 49,8)$ ve erkek nüfus oraları $(\% 50,2)$ (Türkiye İstatistik Kurumu, 2016) arasında çok küçük farklar bulunmaktadır. Bu fark kadınların erkeklere kıyasla turizm eğitimini daha çok tercih ettiklerini düşündürtmektedir. Oysa Tekin (2012:161), Antalya'nın Kemer ilçesinde yaptığı araştırmada; 5 yıldızlı otellerdeki istihdamın \%66'sının erkeklerden, \%34'ünün bayanlardan oluştuğunu tespit etmiştir. Bu sonuç göz önüne alındığında her ne kadar kadınlar turizm eğitimini erkeklerden fazla tercih etseler de, en azından Antalya'nın Kemer bölgesindeki oteller için erkeklerin kadınlardan daha çok istihdam edildiği görülmektedir.

Öğrencilerin ailelerinin aylık toplam gelirleriyle ilgili bulgular, lisans turizm öğrencilerinin büyük bir çoğunluğunun ailelerinin alt ve orta düzey gelir gruplarından oluştuğunu göstermektedir. Dolayısıyla bu durum alt ve orta düzey gelir grubunda yer alan ailelerin çocukları üst düzey gelir grubunda yer alan ailelerin çocuklarına kıyasla turizm eğitimini almayı daha çok tercih ettikleri şeklinde yorumlanabileceği gibi, alt ve orta gelir grubuna mensup kişilerin eğitim ve çalışma hayatını bir arada sürdürme niyetinden de kaynaklanabileceği, ya da alt ve orta gelir grubuna mensup kişilerin puanlarının ancak turizm eğitimi almaya yettiği için turizm bölümünü tercih ettikleri şeklinde de yorumlanabilir.

Bulgular her ne kadar tüm lise türlerinden öğrencinin lisans turizm eğitimi almakta olduğunu ortaya koymuş olsa da; düz lise, Anadolu lisesi, Anadolu turizm ve 
otelcilik lisesi mezunlarının lisans turizm eğitimi almayı daha çok tercih ettikleri, buna karşın fen lisesi, sosyal bilimler lisesi ve imam hatip lisesi mezunlarının lisans turizm eğitimi almayı pek düşünmedikleri söylenebilir. Bu bulgudan hareketle her turizm fakültesi ya da yüksekokul yönetisi ders programlarını ve ders programlarında yer alan derslerin zorluk derecelerini belirlerken kendi öğrencilerinin hangi liselerden geldiğini incelemesi ve gelen öğrencilerin taban ve tavan puanlarını dikkate alması önerilebilir.

Turizm lisans öğrencilerinin genellikle annelerinin eğitim seviyesinin (ortalama eğitim görme süresi yaklaşık olarak 7,38 yıl) babalarından (ortalama eğitim süresi yaklaşık olarak 9,05 yıl) daha düşük olduğu görülmektedir. Anne ve babaların birlikte ortalama eğitim görme süresi yaklaşık olarak 8,2 yıldır. Bu rakam her ne kadar düşük görünüyorsa da 2015 "İnsani Gelişme Raporu”na (Birleşmiş Milletler Kalkınma Programı, 2016) göre, Türkiye'de ortalama eğitim süresinin 7,6 yıl olduğu göz önüne alındığında öğrencilerin anne ve babalarının birlikte ortalama eğitim sürelerinin Türkiye ortalamasından 0,6 yıl daha yüksek olduğu görülmektedir. Anne ve babaların genellikle ilkokul, ortaokul veya lise düzeyinde eğitim kurumlarından mezun oldukları, lisans ve lisansüstü eğitim seviyesinde olan ailelerin çocuklarının turizm eğitimini almaya çok sıcak bakmadıkları düşünülmektedir. Bu bulgu gelir ve öğrencilerin geldikleri liselerle ilgili bulgularla birlikte değerlendirildiğinde lisans düzeyinde turizm eğitimi alan öğrencilerin ağırlıklı olarak düşük eğitimli ve alt gelir grubuna mensup ailelerden geldikleri söylenebilir.

Katılımcı öğrencilerin \%64,8'i şehirde (il, ilçe), \%35,2 kırsalda (köy, belde) ikamet etmekte olan bireylerden oluşmaktadır. 2015 yılı adrese dayalı kayıt sistemine göre şehir nüfus oranı \%92,1, köy nüfus oranı ise \%7,9'dur (Türkiye İstatistik Kurumu, 2016). Nüfus oranındaki dağılıma bakılarak köy ve belde gibi taşra olan yerlerde ikamet etmekte olan bireylerin il ve ilçe merkezinde ikamet eden bireylere kıyasla turizm eğitimini almayı daha çok tercih ettikleri ya da puanlarının ancak turizm eğitimi almaya yettiği için bu bölümleri tercih ettikleri şeklinde yorumlanabilir. Turizmin kentlilerin aktivitesi olduğu, yani turizm faaliyetlerine ağılıklı olarak kentlilerin katıldığı düşünüldüğünde, hizmet alan ile hizmet verenin bir kısmının en azından çocukluk ve ilk gençlik yıllarını daha farklı koşullarda yaşadıkları söylenebilir. Bu durum kültürel farklılık olarak da yorumlanabilir. Bu farklılığın uyumsuzluk oluşturabilme intimali eğitimciler tarafından göz ardı edilmemelidir.

Araştırmaya katılan öğrencilerin büyük çoğunluğunun $(\% 80,5) 1,2$ ve 3 kardeş olduğu dikkate alındığında ailelerin aile planlaması konusunda daha bilinçli olduğu söylenebilir. Bu durum ailelerin eğitim seviyesi ile beraber düşünüldüğünde aile planlaması kavramının artık Türkiye'de hayata geçtiği ya da çok çocuklu ailelerin çocuklarının turizm eğitimi almayı daha az tercih ettikleri de iddia edilebilir.

Katılımcıların TSÇE yönelik tutumlarını ifade eden ölçek maddeleri Tablo 5 'te yer almaktadır. Katıımcıların TSÇE'ne yönelik tutumları genel olarak değerlendirildiğinde; katılımcılar 3,23 ortalama ile turizm sektöründe çalışmanın dezavantajlarının, avantajlarından ağır bastığını düşünmekle birlikte, 3,42 ortalama ile turizmi meslek olanı olarak seçtiklerine memnun oldukları, 3,19 ortalama ile mesleki geleceğini turizm sektöründe gördükleri, 2,47 ortalama ile turizm sektörü dışında çalışmayı düşünmedikleri görülmektedir. Bu sonuç oldukça endişe verici olup, katılımcıların yarısından fazlasının ilerleyen yıllarda turizm sektörü dışındaki sektörlere yönelebileceği, şeklinde yorumlanabilir. Çünkü turizm sektöründe çalışmak isteyen öğrenciler, mezun olup sektörde çalışmaya başladıktan sonra da bir kısmı çeşitli nedenlerle sektörden ayrılabilmektedir. Bir başka bulgu ise, katılımcıların ortalamanın üzerinde bir oranla kız $(3,55)$ ve erkek $(3,15)$ çocuklarının turizm eğitimi almasını ve 
turizm sektöründe çalışmasını istemedikleri, ancak ortalamanın üzerinde $(3,13)$ bir oranla başkalarına tavsiye etmeyi düşündükleri ortaya çıkmıştır. Bu bulgu çelişkili bir sonuç olarak yorumlanabilir. Bu bulgu Kuşluvan ve Kuşluvan'nın (2000) (Öğrencilerin \%56'sı erkek çocuklarının turizm eğitimi almasını ve turizm sektöründe çalışmasını istemediğini, \%72'si kız çocuklarının turizm eğitimi almasını ve turizm sektöründe çalışmasını istemediğini belirtmişlerdir) bulgularıyla karşılaştırıldığında büyük bir değişikliğin olmadığı yani her iki bulgunun büyük oranda örtüştüğü görülmektedir.

Okuduğu bölümü isteyerek seçen katılımcıların TSÇE'ne yönelik tutumları, okuduğu bölümü istemeyerek seçenlere kıyasla anlamlı bir şekilde yüksek değerlere sahip olduğu; 1.sınıfların 2. sınıflardan, 2. sınıfların 3. sınıflardan, 3.sınıfların da 4. sınıflardan TSÇE'ne yönelik tutumlarının daha yüksek olduğu, ayrıca staj/mesleki deneyimi olmayanların staj/mesleki deneyimi olanlara kıyasla TSÇE daha yüksek olduğu ortaya çıkmıştır. Bu bulgular katılımcıların başlangıçta TSÇE yönelik tutumlarının olumlu olduğu, turizm sektörünü yakından görüp, staj/mesleki deneyim sırasında turizm sektöründeki olumsuz çalışma şartlarını gördükçe, çalışma isteklerinin törpülenerek turizm sektöründen soğumaya başladıkları şeklinde değerlendirilebilir. Bu sorunu sektör temsilcileri ve eğitim kurumlarının mutlaka dikkate alması ve soruna koordineli olarak çözüm üretmesi gerekir. Bu sorunun giderilmesi adına turizm işletmelerinde staj/mesleki deneyim yaşayan öğrencilere değişik oryantasyon programları uygulanmalıdır. Ayrıca meslek sevgisinin aşılanarak pekiştirilmesi için öğrencilerin sürekli olarak motive edilmesinin gerektiği düşünülmektedir.

Türkiye'de turizm lisans eğitimi veren fakülte ve yüksekokulların sayısı ile öğrenci sayısı her geçen gün artmaktadır. Bu durum sürekli büyümekte olan Türk turizm sektörü adına olumlu bir gelişme olarak değerlendirilebilir. Çünkü mesleki eğitim alan kişi sayısının artması, turizm sektörünün kalifiye personel ihtiyacını karşılayabilmesi adına umut verici bir gelişmedir. Ancak turizm eğitimi almış dinamik genç bireylerin turizm sektörü dışındaki sektörlere yönelmeleri Türk turizm sektörünün gelişimi ve geleceği adına endişe verici vahim bir sorun olarak görülmektedir. Bu sorun sektör temsilcileri ve turizm eğitim kurumlarınca masaya yatırılmalı ve üzerinde önemle durulmalıdır.

\section{Kaynakça}

Avcıkurt, C.,Deveci, B. ve Türkmen, S. (2012), 'Balıkesir Üniversitesi Turizm İşletmeciliği ve Otelcilik Yüksekokulu (BTiYO) mezunlarının turizm sektöründeki istihdam profili' içinde Turizm eğitimi konferans-workshop kitabı, ss.109-119, Turizm Eğitimi Konferansı, Ankara.

Aymankuy, Y. ve Aymankuy, Ş. (2013) 'Turizm işletmeciliği eğitimi alan öğrencilerin turizm sektöründeki istihdamla ilgili görüşleri ve sektördeki kariyer beklentileri (Balıkesir Üniversitesi turizm işletmeciliği ve otelcilik yüksekokulu örneği)' Akademik Bakış Dergisi, (35), ss.1-21.

Baltacı, F., Üngüren, E., Avsallı, H. ve Demirel, O.N. (2012), 'Turizm eğitimi alan öğrencilerin eğitim memnuniyetlerinin ve geleceğe yönelik bakış açıların belirlemesine yönelik bir araştırma' Uluslararası Alanya Işsletme Fakültesi Dergisi, 4(1), ss.17-25.

Birleşmiş Milletler Kalkınma Programı, İnsani Gelişme Raporu 2015, Türkiye, www.tr.undp.org/content/turkey/tr/home/countryinfo.html (26.10.2016).

Ehtiyar, R. ve Üngören, E. (2008), 'Turizm eğitimi alan öğrencilerin umutsuzluk ve kaygı seviyeleri ile eğitime yönelik tutumları arasındaki ilişkinin belirlenmesine yönelik bir araştırma' Uluslararası Sosyal Araştırmalar Dergisi, 1(4), ss.159-181. 
Gee, Y. C. (1994), International hotels development and management, Educational institue of the AHMA., ABD.

Jiang, B. ve Tribe, J. (2009), 'Tourism jobs-short lived professions: student attitude towards tourism careers in China' Journal of Hospitality, Leisure, Sport \& Tourism Education, 8(1), ss.4-19.

King, B., Mc Kercher, B. ve Waryszak, R. (2003), 'A comparative study of hospitality and tourism graduates in Australia and Hong Kong' International Journal of Tourism Research, 5(6), ss.409-420.

Kozak, M.A. ve Kızılırmak, İ. (2001), 'Meslek yüksekokulu turizm ve otelcilik programları öğrencilerinin turizm sektörüne yönelik tutumları' içinde Turizm işletmelerinde insan kaynakları yönetimi, ss.205-217, Hafta Sonu Seminerleri VII Nevşehir.

Kuşluvan, S. ve Kuşluvan, Z. (2000), 'Perceptions and attitudes of undergraduate tourism students towards working in the tourism industry in Turkey' Tourism Management, 21(3), ss.251-269.

Lu (Ying), T. ve Adler, H. (2009), 'Career goals and expectation of hospitality and tourism students in China' Journal of Teaching in Travel \& Tourism, 6, ss.63-80.

Milli Eğitim Bakanlığı Mesleki ve Teknik Eğitim Araştırma ve Geliştirme Merkezi Başkanlığı (MATARGEM) (2000), 'Turizm sektörünün Ara Kademe Insan Gücü Ihtiyacı ve Turizm Eğitimi Araştırmas', (Yayın No: 26).

OSYM (2015), 'Yüksek Öğretim Programları ve Kontenjanları Klavuzu' www.osym.gov.tr/pdfdokuman/2015/OSYS/2015-

SYSKONTKLAVUZU15072015.pdf (26.08.2015).

Pavesic, D.V. ve Brymer, R.A. (1990), 'Job satisfaction: What's happening to the young managers?' The Cornell Hotel and Restaurant Admistration Quarterly, 30(4), ss.90-96.

Richardson, S. (2009), 'Undergraduates' perceptions of tourism and hospitality as a career choice' International Journal of Hospitality Management, 28(3), ss.382388.

Robinson, M. (2001), 'Tourism encounters: Inter and intra cultural conflicts and the World's largest industry' içinde Nezar AlSayyad (Editör), Consuming tradition, manufacturing heritage: Global norms and urban forms in the age of tourism (ss.34-67). Newyork: Routlegde.

Roney, S.A. ve Öztin, P. (2007), 'Career perceptions of undergraduate tourism students in Turkey' Journal of Hospitality, Leisure, Sport And Tourism Education, 6(1), ss.4-17.

Ross, G.F. (1994), 'What do Australian school leavers want of the industry?' Tourism Management, 15(1),ss. 62-66.

Solmaz, S.A. ve Erdoğan, Ç. (2013), 'Turizm eğitimi alan lisans ve ön lisans öğrencilerinin turizm endüstrisine bağlılık düzeylerinin belirlenmesine yönelik bir araştırma' içinde 14. ulusal turizm kongresi bildiriler kitabı, ss.557-573, 14. Ulusal Turizm Kongresi Kayseri.

Tekin, Ö. (2012), Yabancılaşma ve beş faktör kişilik özellikleri arasındaki ilişkiler: Antalya Kemer'deki beş yıldızlı otel işletmeleri çalışanları üzerinde bir uygulama, Yayınlanmamış doktora tezi, Akdeniz Üniversitesi, Sosyal Bilimler Enstitüsü, Antalya.

Türkiye İstatistik Kurumu (2016), 'Cinsiyete göre nüfus oranları?' www.tuik.gov.tr/PreTablo.do?alt-id=1068 (11.05.2016).

Türkiye İstatistik Kurumu (2016), 'Şehir-köy nüfus oranları?' www.tuik.gov.tr/PreTablo.do?alt-id=21519 (11.05.2016).

Unur, K. ve Köşker, H. (2015), 'Türkiye'de turizm eğitimi ve turizm eğitimi alan öğrencilerin turizme bakış açılarına yönelik araştırmaların incelenmesi' Cag University Journal of Social Sciences, 12(1), ss.44-71. 
Ünlüönen, K. ve Boylu, Y. (2005), Türkiye'de yüksek öğretim düzeyinde turizm eğitimindeki gelişmelerin değerlendirilmesi [elektronik versiyon]. Elektronik Sosyal Bilimler Dergisi, 3(12), ss.11-32.

Walmsley, A. (2004), 'Assessing staff turnover: a view from the English Riviera' Internatıonal Journal of Tourısm Research, 6, ss. 275-287.

Yıldız, S.B. (2013), 'Lisans düzeyinde turizm eğitimi alan öğrencilerin sektörde çalışmaya yönelik bakış açıları' İ̧inde 14. ulusal turizm kongresi bildiriler kitabı, ss.595-614, 14. Ulusal Turizm Kongresi Kayseri.

Yüksek Öğretim Kurumu (2016), 'Lisans Turizm Öğrenci Sayısı?' www.yokatlas.yok.gov.tr/lisans.php?y=107410587 (02.01.2016). 